\title{
SISTEM HIBAH DALAM PEMBAGIAN WARISAN PERSPEKTIF KESETARAAN GENDER
}

\author{
1Waro Satul Auliyak dan ${ }^{2}$ Noer Azizah \\ 1,2UIN Maulana Malik Ibrahim Malang \\ auliyawaro@gmail.com \\ azizahaqenje97@gmail.com
}

\begin{abstract}
The distribution of inheritance in Bukabu Village, Ambuten Sub-District, Sumenep District uses a grant system. This has become a custom in that area. The treasure will be given before the heir dies. The heirs receive grants as adults or married. The purpose of this study is to describe the practice of grants in inheritance distribution in Bukabu Village, Ambuten Sub-District, Sumenep District, which will be analyzed using the concept of gender equality. This research method uses a qualitative approach, in a qualitative approach descriptive data will be obtained, namely data obtained from respondents either in writing or verbally as well as real behavior. The research results show that the distribution of inheritance uses a grant system. The assets are given before the heir dies and the heirs get the inheritance when they are adults or are married. The existence of this grant system can minimize inheritance disputes. The share for all heirs is no different, be it male or female. Where it is known that the people of Bukabu Village share their inheritance equally, for both boys and girls, they argue that the distribution is only based on the customary law that applies in the area.
\end{abstract}

Keywords: Gender Equality, Grant System, Inheritance

\section{Abstrak}

Pembagian warisan di Desa Bukabu, Kecamatan Ambuten, Kabupaten Sumenep menggunakan sistem hibah. Hal tersebut telah menjadi adat di tempat tersebut. Harta akan diberikan sebelum pewaris meninggal. Ahli waris mendapatkan hibah setelah dewasa atau telah menikah. Tujuan dari penelitian ini untuk mendeskripsikan praktek hibah dalam pembagian warisan di Desa Bukabu, Kecamatan Ambuten, Kabupaten Sumenep, yang akan dianalisis menggunakan konsep kesataran gender. Metode penelitian ini menggunakan pendekatan kualitatif, pada pendekatan kualitatif akan didapatkan data deskriptif, yakni data yang didapat dari responden baik itu secara tertulis ataupun secara lisan serta perilaku yang nyata. Adapun hasil penelitian menunjukkan bahwa pembagian harta warisan menggunakan sistem hibah. Harta tersebut diberikan sebelum pewaris meninggal dan Ahli waris mendapatkan warisan ketika dewasa atau sudah menikah. Adanya sistem hibah ini dapat meminimalisir terjadinya sengketa waris. Bagian untuk semua ahli waris tidak ada perbedaan, baik itu laki-laki ataupun perempuan. Dimana telah diketahui bahwa masyarakat Desa Bukabu membagi harta warisannya dengan sama rata, baik untuk anak laki-laki maupun perempuan, 
mereka berdalih bahwa pembagian tersebut hanya didasarkan pada hukum adat yang berlaku di daerah tersebut.

Kata Kunci: Kesetaraan Gender, Sistem Hibah, Warisan

\section{PENDAHULUAN}

Pembahasan terkait waris serta hibah telah banyak diulas dalam jurnal-jurnal lainnya. Seperti jurnal yang ditulis oleh Aminuddin, Usman Jafar dan Supardi yang berjudul Hibah Sebagai Alternatif Pembagian Harta Pada Masyarakat Suku Pattae (Telaah Atas Hukum Islam). Pada penelitian tersebut didapatkan informasi bahwa hibah yang dilaksanakan oleh suku Pattae dilakukan secara berimbang, kemudian juga terdapat surat tanda bukti kesepakatan dialihkannya harta dan orang tua dapat menarik kembali harta tersebut jika terjadi suatu hal yang tidak diharapkan (Aminuddin dan Supardi, 2018). Kemudian jurnal yang ditulis oleh Patampari (2016) yang berjudul Pelaksanaan Hibah dan Wasiat dikalangan Masyarakat Kabupaten Bone. Dari penelitian ini dapat diketahui bahwa alasan masyarakat Bugis Bone melaksanakan hibah adalah menghindari adanya perselisihan serta ketidakpahaman mereka dengan sistem kewarisan. Sedangkan penelitian ini hadir membahas tentang sistem hibah dalam pembagian warisan di Desa Bukabu, Kecamatan Ambuten, Kabupaten Sumenep, yang mana kemudian akan dianalisis menggunakan konsep kemaslahatan.

Setiap hukum yang diturunkan oleh Allah tentunya mempunyai tujuan, sebagaimana al-Syatibi dalam memberikan pengertian dari maqashid syariah yaitu tujuan dari hukum yang telah diturunkan oleh Allah SWT. Kemudian al-Syatibi juga mengemukakan bahwa maqashid syariah atau tujuan dari syariat adalah menciptakan kemaslahatan bagi semua manusia. Semua kewajiban diciptakan untuk merealisasikan kemaslahatan bagi hambanya, tidak terdapat satupun hukum Allah SWT yang tidak memiliki tujuan (Mawardi, 2010). Kemaslahatan disini bertujuan untuk menjaga atau memelihara agama, akal, harta, jiwa serta keturunan/kehormatan, yang mana lima hal tersebut adalah kebutuhan pokok yang dapat menegakkan kehidupan manusia. Jika kelima hal tersebut dapat terpelihara dengan baik maka dapat mewujudkan kemaslahatan baik lahir maupun batin, kemudian juga kemaslahatan bagi setiap individu maupun masyarakat, serta kemaslahan di dunia dan akhirat (Suratmaputra, 2017).

Pembagian warisan biasanya dilakukan setelah pewarisnya meninggal. Namun hal tersebut berbeda dengan pembagian warisan yang terjadi di Desa Bukabu, Kecamatan Ambuten, Kabupaten Sumenep, yang membagi warisan dengan sistem hibah. Masyarakat di Desa Bukabu 
berseberangan dengan sistem waris Islam, sistem hibah yang digunakan agar tidak terjadi pertikaian di kemudian hari. Hibah tersebut diberikan kepada anaknya ketika anaknya telah dewasa atau telah menikah. Dimana hartanya dibagi secara seimbang, tidak ada bagian laki-laki lebih banyak atau perempuan lebih sedikit. Semua mendapatkan bagian yang sama. Hal tersebut tentunya berbeda dengan sistem waris yang ada dalam Islam, yang mana laki-laki dan perempuan tidak mendapatkan bagian yang sama.

Berdasarkan gambaran permasalahan di atas maka tujuan dari penelitian ini adalah untuk mendeskripsikan terkait sistem hibah yang digunakan untuk pembagian warisan di Desa Bukabu, Kecamatan Ambunten, Kabupaten Sumenep. Selanjutnya sistem hibah yang digunakan untuk membagi warisan tersebut akan dianalisis menggunakan perspektif gender.

\section{METODE}

Penelitian ini menggunakan pendekatan kualitatif deksriptif, dan dilakukan di Desa Bukabu, Kecamatan Ambuten, Kabupaten Sumenep. Teknik pengumpulan data menggunakan teknik wawancara, observasi, dan studi dokumentasi.

\section{HASIL PENELITIAN DAN PEMBAHASAN Waris}

Hukum waris ialah bagian dari hukum keluarga yang memegang peranan penting, bahkan sistem ini adalah sistem yang juga berada di masyarakat. Hukum ini adalah sistem yang mengatur tentang peralihan harta seseorang yang telah meninggal dunia kepada orang yang masih hidup, karena hukum waris tersebut mengatur tentang proses harta benda dan barang-barang yang berwujud dari keturunannya.

Perihal waris dalam Islam merupakan masalah yang sangat tuntas dijelaskan dalam al-Quran. Jika tidak ada firman Allah, maka tradisi jahiliyah bangkit lagi, dan setiap orang akan membagi sesuai keinginannya. Fungsi dari Kalamullah ialah pembagiannya sistematis, jelas, agar terhindar dari konflik antar keluarga, kerabat dan sesama saudara dalam pembagian waris.

Dalam sutau riwayat bahwasanya Rasulullah SAW bersama Abu Bakar pergi ke desa Bani Salamah untuk menjenguk Jabir Bin Abdillah yang sedang sakit. Saat beliau menemuinya Jabir dalam keadaan pingsan, kemudian beliau meminta air untuk berwudhu' dan memercikkan air ke wajahnya, sehingga Jabir pun sadar kembali. Lalu Jabir berkata "apa yang tuan perintahkan terhadap harta bendaku?"(Saebani, 2009). Pertanyaan tersebut dijawab oleh Rasullullah sebagaimana yang terdalam dalam surat An-Nisa' 11-12. Yang kemudian dijadikan pedoman dalam pembagian waris naungan Islam. 


\section{Sebab-sebab Hubungan Kewarisan}

Aspek yang bisa memproleh hak warisan yakni ada tiga sebab, yakni (Saebani, 2009):

a. Keluarga mutlak, seperti kedua orang tua, anak, saudara, paman, dan seterusnya.

b. Perkawinan secara shahih, seorang dapat mendapatkan warisan disebabkan adaya pertalian perkawinan si mayit dengan seseorang yang ditinggal.

c. Al-wala', yakni kekerabatan dikarenakan sebab hukum. Penyebabnya yang dikarenakan kenikmatan pembebasan budak yang dilakukan oleh seseorang disebut wala an-ni'mah. Sedangkan perihal membebaskannya akan mendapat suatu kenikmatan yaitu berupa kekerabatan maka dinamakan wala al-itqi.

\section{Sebab-sebab Tidak Menerima Waris}

Penghalang untuk menerima waris para ulama sepakat ada tiga sebab, yakni (Saebani, 2009):

a. Perbedaan agama, para ulama bersepakat bahwa seorang muslim tidak dapat mewariskan hartanya terhadap non muslim. Orang muslim hanya dapat memberikan waris kepada muslim.

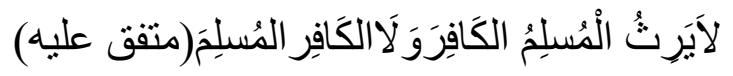

"Orang islam tidak mendapat warisan dari orang kafir, dan orang kafir tidak memperoleh warisan dari orang Islam, (HR. Mutafaq Alaih)."

b. Pembunuhan, apabila pewaris dibunuh oleh ahli waris, maka ia tidak berhak memperoleh warisan, sebagaimana sabda Nabi SAW:

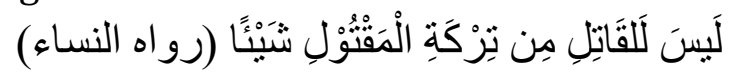

"Pembunuh tidak berhak mewarisi harta yang dibunuhnya, (HR. AnNasai)."

c. Perbudakan, seseorang yang bestatus sebagai budak tidak mempunyai hak waris, sekalipun warisan tersebut berasal dari saudaranya. Hal tersebut karena semua yang dimiliki seorang budak berarti menjadi milik tuannya. Sebagaimana dalam surat An-Nahl difirmankan:

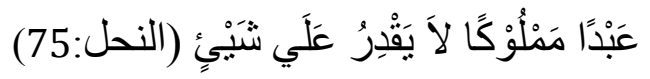

"Hamba sahaya yang dimiliki yang tidak dapat bertindak terhadap sesuatu apapun."

\section{Rukun dan Syarat Waris}

Untuk membuktikan warisan, maka terdapat tiga syarat yang harus dipenuhi, yakni (Ajib, 2019):

a. Matinya pewaris, yang mana kematian pewaris harus dapat dibuktikan baik secara hakiki, hukum, serta taqdiri. 
b. Hidupnya ahli waris, yang mana hidupnya tersebut juga harus berwujud, bisa dengan kehidupan hakiki dan tetap atau disamakan dengan orangorang yang masih hidup dengan perkiraan.

c. Apabila tidak ada penghalang yang membagi pewarisan.

\section{Hibah}

Dalam kamus al-Quran hibah ialah pemberian yang diperuntukkan kepada seseorang masih hidup, dengan tidak mengharapkan balasan atau ikatan baik secara lisan ataupun tertulis (al-Hafidz, 2006). Sedangkan menurut Ibn Abidin adalah akad pemberian kepemilikan kepada orang lain tanpa adanya ganti, pemberian secara sukarela dan diberika pada masa hidupnya.

Sabiq (2014) mengemukakan terkait pengertian hibah, yaitu akad yang berisi pemberian harta yang dilakukan oleh seseorang kepada orang lain yang dilakukan ketika ia masih hidup, pemberian tersebut tanpa adanya penukar. Jika seseorang tersebut tidak memberikan harta tersebut, namun hanya memberikan izin kepada orang lain untuk mengambil manfaat dari harta tersebut, maka hal tersebut bukan termasuk hibah melainkan termasuk peminjaman.

Sehingga bisa disimpulkan hibah adalah akad perjanjian yang objeknya termasuk pemberian harta ataupun benda oleh seseorang kepada orang lain, yang mana akad tersebut dilaksanakan ketika kedua belah pihak masih hidup serta tanpa mengaharapkan imbalan. Hibah tersebut ialah bentuk salah satu pendekatan diri kepada Allah, untuk memperluwes hubungan keluarga serta memupuk rasa setia dan kepedulian sosial. Hibah tersebut lebih baik diberikan kepada kerabat karna didalamnya terdapat unsure silaturrahmi.

\section{Rukun dan Syarat Hibah}

Jumhur ulama menyatakan bahwa rukun hibah ada 4 (empat), diantaranya (Ajib, 2019):

a. Orang yang memberi (al-wahib), maksdunya dia adalah pemilik barang ketika dalam keadaan sehat dan mempunyai kewenangan.

b. Orang diberi (al-mauhub lah), adapun orang yang diberi diperuntukkan kepada siapa saja yang dikendaki.

c. Benda yang diberikan (al-mauhub), benda tersebut adalah benda yang dapat dijadikan sebagai hak milik untuk dihibahkan, misalnya benda bergerak maupun benda tidak bergerak.

d. Sighat, maksudnya ialah ijab qabul. 


\section{Macam-macam Hibah}

Macam-macam hibah ada dua kategori dalam fiqih, diantaranya (Ajib, 2019):

a. Hibah manfaat yang dikenal dengan hibah umra, yakni orang yang mmeperoleh hibah hanya memdapatkan manfaatnya saja. Jika orang tersebut telah meninggal, maka pokok barang yang telah dihibahkan akan kembali kepada orang yang memberikan hibah.

b. Hibah ruqba, yakni pemberi hibahnya meninggal terlebih dahulu, maka benda hibah tersebut menjadi milik penerima hibah.

\section{Kesetaraan Gender}

Gender merupakan suatu konsep yang biasa digunakan untuk mengidentifikasi perbedaan laki-laki dan perempuan. Sebelum itu, kita harus memahami konsep gender itu sendiri dan sex. Sex ialah female atau jenis kelamin manusia yang bias dilihat secara biologis. Secara biologis yang dimiliki perempuan tidak bisa ditukarkan ke alat bologis lain jenis (Sugihastuti dan Sastriyati, 2007).

Gender merupakan istilah yang memiliki makna pembagian peran sosial atara laki-laki dan perempuan dan mengacu pada ciri emosional dan psikologis yang diharapkan oleh budaya daerah masing-masing. Gender juga termasuk kelompok kata yang memilii sifat maskulin, feminim, atau netral. Maka dari itu gender sering dikaitkan dengan ketidak adilan. Oleh sebab itu, peran gender itu tidak universal, karena non kodrati, non biologis, dan berasal dari kontruksi sosial budaya (Sidik, 2004).

Sebelum Islam datang adanya ketimpangan antara laki-laki dan perempuan dalam starata sosial, nasib perempuan sangat memprihatinkan. Di kehidupan keluarga sendiri istri berada di bawah naungan suaminya, sepertinya perempuan tidak mempunyai hak yang semestinya. Kemudian islam memberikan cahaya baru sehingga perempuan bisa terangkis dalam kegelapannya, sepeti halnya didalam al-Quran sudah terdapat surah yang menjelaskan tentang perempuan yang tertuang dalam Kalam Allah dalam surahnya An-nisa'. Di samping itu dalam pandangan Islam laki-laki dan perempuan dianggap sama dalam ranah kemanusiannya tertuang dalam surat Al-Hujarat ayat 13, namun kesamarataan ini bukan menjadikan perempuan sama persis dengan laki-laki dalam ruang lingkup besar. Pastinya ada batasan-batasan yang membedakan.

Konsep seks, gender bia diartikan sauatu dasar yang membedakan laki-laki dan perempuan dalam ranah kebudayaan atau kehidupan, sehingga dari itu kita bisa melihat perbedaan baik dari segi sosial dan budaya. Konsep gender condong terhadap seperangkat sifat, peran, fungsi, tanggung jawab, hak dan perilaku yang melekat akibat pembentukan budaya dan pola hidup. 
Dalam ranah masyarakat perempuan masih berada dibawah kekuasaan laki-laki, disebabkan peranan laki-laki yang lebih dominan keuasaannya, dimana kesatara gender merupakan salah satu dari hak asasi manusia. Kebebasan yang berkaadilan menuntut kesetaraan antara laki-laki dan perempuan. Kebebasan berkeadilan, artinya terdapat perbedaan kekuasaan yang adil antara laki-laki dengan perempuan karena perbedaan biologis antara keduanya. Keadialan yang fair berarti kesamaan dalam kesempatan dan pemamfaatan sumber-sumber dalam hidup bersama, dapat saja terjadi terdapat keadilan dalam kehidupan bersama dalam masyarakat dalam berbagai bidang (Sumar, 2015).

Makna kesetaraan sering merujuk pada hak dan kewajiban antara laki-laki dan perempuan. Pembahasan kesetaraan gender seringkali menjadi direvasi dari pembahasan feminisme, kesataran gender dan emansipasi. Kata tersebut sudah lama didengungkan di Indonesia sebagai gerakan untuk memberikan posisi yang sama antara laki-laki dan perempuan. Feminism sebagai sebuah gerakan atas ketidak adilan peranan laki-laki dan perenpuan yang mendapat dukunga secara hukum internasioanl.

Sejarah pemikiran femisnisme mempelihatkan adanya beberapa aliran feminisme, diantaranya liberal, sosial, dan anarkis. Akiran feminisme liberal berusaha menyadarkan wanita bahwa sebagai golongan tertindas, feminisme anarkis anarkis termasuk gerkan yang beranggapan bahwa system patriarki sebagai permasalahan yang harus dibasmi, feminisme sosial merupakan gerakan yang menawarkan konsep tidak ada sosialisme tanpa pembebasan perempuan sehinga bentuk kepemilikan perempuan beserta hartanya oeh laki-laki karena adanya perkawinan, harus dihapuskan (Permana, 2018).

\section{Pembagian Harta Warisan di Desa Bukabu Ambunten Sumenep}

Pelaksanan pembagian harta warisan pada masyarakat Madura bermacam cara, ada yang menggunakan faraidh, ada yang menggunakan sistem hibah. Saat wawancara, kami mendapatkan informasi dari beberapa penduduk mengenai sistem waris yang dijalankan oleh masyarakat Bukabu Ambunten. Ada masyarakat yang membagikan hartanya sebelum pewaris tersebut meninggal dunia dengan dilandaskan pada hukum adat. Namun juga terdapat masyarakat yang tetap berpegang pada pembagian waris yang didasarkan pada hukum Islam.

Kenyataan warga membagi harta warisan dalam jarak waktu yang sangat lama. Responden menyebutnya mebutuhkan waktu untuk pembagian harta secara baik. Pembagian warisan yang dilakukan sebelum pewaris meninggal disebut juga dengan hibah. Pembagian warisan dengan sistem hibah dilakukan ketika ahli warisnya telah dewasa atau sudah menikah. Sehingga ketika menikah harta yang diberikan oleh pewaris dapat digunakan 
untuk menata hidup yang baru. Menurut informasi dari responden, di Desa Bukabu tidak pernah ditemukan kasus sengketa dalam hal pembagian harta warisan, apalagi sampai dibawa ke pengadilan. Hal tersebut karena pembagian warisan yang dilakukan sebelum pewaris meninggal sehingga dapat meminimalisir pertikaian atau sengketa dalam pembagian harta warisan. Seperti dalam harta warisan yang berupa tanah, dimana setelah diberikan kepada masing-masing ahli waris sertifikat tanah tersebut akan langsung diubah atas nama ahli waris.

Pembagian warisan dengan sistem hibah sendiri dilakukan tanpa adanya bukti tertulis, hanya penyampaian secara lisan dari pewaris. Namun tindak lanjut dari penyampaian secara lisan tersebut yaitu dengan langsung memberikan hartanya dan merubah sertifikat sesuai dengan nama ahli waris. Kemudian masyarakat dalam membagi warisan disamaratakan, baik itu untuk anak laki-laki maupun untuk anak perempuan. Tidak terdapat perbedaan dalam bagian.

Contoh dalam pembagiannya, di Madura khsusnya desa Bukabu mayoritas pekerjaannya ialah petani, jadi sebelum si pewaris meninggal dunia, maka dia memberikan beberapa petak tanah dengan cara disamaratakan kepada anaknya. Jika tanahnya ada 4 ladang, dan anaknya ada 2, maka per saudara mendapatkan masing-masing 2 petak tanah.

\section{Sistem Hibah dalam Waris}

Telah kita ketahui bersama bahwa hukum waris Islam ketika diterapkan sesuai dengan ketentuan kitab fiqih klasik masih menimbulkan berbagai masalah apabila dibenturkan pada keadaan realita sosial masyarakat Indonesia. Sebagian masyarakat di Indonesia memiliki kecenderungan untuk memberikan bagian yang sama antara anak laki-laki dengan perempuan, mereka tidak ingin membedakan keduanya dalam hal pembagian waris.

Hibah yang dilakukan oleh orang tua terhadap anaknya dapat diperhitungkan sebagai harta warisan, sebagaimana yang telah diketahui bahwa hal tersebut telah menjadi tradisi atau kebiasaan yang dilakukan oleh masyarakat khususunya di Desa Bukabu, Kecamatan Ambunten, Kabupaten Sumenep. Pemberian harta tersebut dilaksanakan ketika anak-anak mereka telah menginjak usia dewasa atau telah menikah.

Jika melihat konteks yang terjadi di Desa Bukabu dengan menganalisa bahwa membagi harta warisan dengan sistem hibah sewaktu pewaris masih hidup, dengan maksud agar anak laki-laki dan anak perempuan mendapat bagian yang sama tidak bisa dipungkiri, bahkan hal itu merupakan sebuah solusi dalam waris Islam, bahkan ada riwayat dari al-Thabrani dan alBayhaqi dari Ibn Abas RA, bahwa Nabi SAW bersabda (Azni, 2015): 
"Samakanlah pemberian yang kamu lakukan terhadap anak-anakmu, dan sekiranya hendak melebihkan, maka hendaklah kelebihan itu diberikan kepada anak perempuan".

Pemberian hibah yang diberikan oleh orang tua terhadap anaknya dapat diperhitungkan sebagai harta warisan, sebagaimana yang terdapat dalam Pasal 211 Kompilasi Hukum Islam (KHI). Pada pemberian hibah yang terpenting adalah adanya musyawarah dan terdapat persetujuan dari semua pihak. Sistem waris yang seperti ini ketika dibenturkan dengan aspek maslahah mursalah, maka Sistem seperti ini bisa digunakan apabila dalam keadaan darurat. Sistem ini tidak menjadi keharusan, melainkan hanya sebagai alternatif dalam situasi tertentu. Misalnya ada persengketaan antara ahli waris yang sudah mendapatkan hibah dan ahli waris yang belum mendapatkan hibah yang belum mendapatkan hibah dalam pembagian waris setelah orang tua meninggal dunia.

Berkaitan dengan sistem hibah dalam pembagian harta warisan jika ditinjau dari kemaslahatan maka dapat diperbolehkan. Mengingat maslahah merupakan segala hal yang mendatangkan segala bentuk kemanfaatan atau menolak segala kemungkinan yang rusak. Penggunaan sistem hibah dalam pembagian warisan yang dinilai masyarakat dapat meminimalisir sengketa maka dianggap mendatangkan manfaat bagi masyarakat. Selain itu penerapan maslahah tidak ada yang murni, ukurannya dapat ditentukan jika maslahah lebih kuat maka disebut dengan maslahah. Berdasarkan hal tersebut tentunya telah diketahui bahwa maslahah menggunakan sistem hibah dalam pembagian harta warisan lebih kuat dari pada mafsadahnya. Hal tersebut sejalan dengan maslahah daruriyah, yang mana segala sesuatu yang harus ada demi tegaknya kehidupan manusia untuk menopang kemaslahatan agama dan dunia.

\section{Analisa Sistem Hibah dalam Waris Persepektif Kesetaraan Gender}

Sebagaimana yang telah diketahui bahwa kesetaraan gender mulai banyak diperbincangkan di era sekarang. Terdapat banyak hak-hak serta kewajiban bagi laki-laki maupun perempuan yang dikaitkan dengan kesetaraan gender. Jika ditelaah lagi, maka dapat diketahui bahwa kesetaraan gender mulai digaungkan ketika datangnya ajaran agama Islam. Seperti yang telah diketahui bahwa perempuan di zaman jahiliyyah nasibnya sangat memprihatinkan, mereka tidak memperoleh hak-haknya sebagaimana semestinya. Nasib perempuan-perempuan di zaman jahiliyyah mulai membaik ketika datangnya ajaran agama Islam, dimana Islam mulai memberikan hak-hak yang semestinya bagi para perempuan, salah satunya yaitu hak untuk menerima harta warisan. Islam mengatur pembagian harta warisan secara sistematis dan jelas baik untuk laki-laki maupun perempuan. 
Kesetaraan sering merujuk pada hak serta kewajiban antara laki-laki dan perempuan. Pembahasan kesetaraan gender seringkali menjadi direvasi dari pembahasan feminisme, kesataran gender dan emansipasi. Kata tersebut sudah lama didengungkan di Indonesia sebagai gerakan untuk memberikan posisi yang sama antara laki-laki dan perempuan. Kesetaraan gender yang mulai didengungkan tersebut tentunya juga menyentuh berbagai hak-hak yang didapatkan oleh laki-laki dan perempuan, salah satunya yaitu waris. Sebagaimana yang telah kita ketahui, bahwa Islam mengatur bagian untuk laki-laki lebih banyak dari pada perempuan dalam hal pembagian harta warisan. Selain itu juga didukung dengan fakta bahwa masih banyak masyarakat Indonesia yang menganut sistem patriaki, dimana menempatkan laki-laki sebagai pemegang kekuasaan, sehingga semua otoritas baik terhadap keluarga maupun harta benda semua diserahkan kepada laki-laki. Tentunya hal tersebut dianggap menjadi sesuatu yang tidak setara, sehingga banyak perempuan-perempuan yang aktif menggaungkan kesetaraan gender.

Jika dikaitkan dengan pembagian harta warisan yang dilakukan oleh masyarakat Desa Bukabu, Kecamatan Ambuten, Kabupaten Sumenep, maka dapat dikatakan bahwa masyarakat desa tersebut sedikit banyak telah menganut kesetaraan gender. Dimana telah diketahui bahwa masyarakat Desa Bukabu membagi harta warisannya dengan sama rata, baik untuk anak laki-laki maupun perempuan. Meskipun hal tersebut mungkin saja tidak disadari oleh masyarakat Desa Bukabu, karena mereka berdalih bahwa perbagian tersebut hanya didasarkan pada hukum adat yang berlaku didaerah tersebut. Kenyataan pembagian harta warisan yang dibagi dengan sama rata, terbukti tidak menimbulkan banyak konflik. Meskipun hal tersebut juga didukung oleh pembagian harta warisan dengan sistem hibah, dimana pembagian harta tersebut dilakukan ketika pewaris masih hidup.

Permasalahan-permasalahan waris yang timbul karena adanya anggapan tidak ada kesetaraan dalam pembagian waris antara laki-laki dan perempuan, dapat diatasi dengan sistem pembagian yang diterapkan oleh masyarakat Desa Bukabu. Namun penerapan sistem tersebut tentunya harus seizin pewaris dan semua ahli waris, sehingga tidak ada permasalahan dikemudian hari. Karena hakikat pembagian waris didasarkan pada kerelaan masing-masing pihak. Sehingga, jika telah ada kerelaan dari masing-masing pihak maka harta waris dapat dibagi dengan sistem hibah dan bagiannya disamaratakan.

\section{KESIMPULAN}

Masyarakat di desa Desa Bukabu, Kecamatan Ambuten, Kabupaten Sumenep dalam membagi harta warisan mayoritas menggunakan sistem hibah. Harta tersebut diberikan sebelum pewaris meninggal. Ahli waris 
mendapatkan warisan ketika dewasa atau sudah menikah. Adanya sistem hibah ini dapat meminimalisir terjadinya sengketa waris. Bagian untuk semua ahli waris tidak ada perbedaan, baik itu laki-laki ataupun perempuan. Dimana telah diketahui bahwa masyarakat Desa Bukabu membagi harta warisannya dengan sama rata, baik untuk anak laki-laki maupun perempuan. Meskipun hal tersebut mungkin saja tidak disadari oleh masyarakat Desa Bukabu, karena mereka berdalih bahwa pembagian tersebut hanya didasarkan pada hukum adat yang berlaku di daerah tersebut. Jika dikaitkan dengan pembagian harta warisan yang dilakukan oleh masyarakat Desa Bukabu, Kecamatan Ambuten, Kabupaten Sumenep, maka dapat dikatakan bahwa masyarakat desa tersebut sedikit banyak telah menganut kesetaraan gender.

\section{DAFTAR PUSTAKA}

Ajib, Muhammad. (2019). Fiqih Hibah dan Waris, Jakarta: Rumah Fiqih Publishing,

Al-Hafidz, Ahsin W. (2006). Kamus Ilmu AL-Quran, Jakarta: Amzah.

Aminuddin, Jafar Usman, dan Supardi. (2018). Hibah Sebagai Alternatif Pembagian Harta Pada Masyarakat Suku Pattae (Telaah Atas Hukum Islam), Jurnal Diskursus Islam, 2, Agustus.

Azni. (2015). Eksistensi Hibah dalam Posibilitas Pembatalannya dalam Persepektif Hukum Islam dan Hukum Positif di Indonesia. An-Nida: Jurnal Pemikiran Islam, 40(2).

Mawardi, Ahmad Imam. (2010). Fiqh Minoritas: Fiqh Al-Aqalliyyat dan Evolusi Maqashid al-Syari'ah dari konsep ke Pendekatan, Yogyakarta: LKiS,

Patampari, Ahmad Supandi. (2016). Pelaksanaan Hibah dan Wasiat dikalangan Masyarakat Kabupaten Bone, Ar-Risalah, 2 (Juli-Desember).

Permana, Sugiri. (2018). Ijtihad Kesetaraan Gneder dalam Ijtihad Hukum Waris di Indonesia. ASy-Syari'ah, 20(2).

Saebani, Ahmad Beni. (2009). Fiqih Mawaris, Bandung: CV Pustaka Setia Bandung.

Sabiq, Muhammad Sayyid. (2014). Fiqhu As-Sunnah, Penerjemah Ahmad Cornish Creative (ACC), Depok: Fthan Media Prima, Jilid ke.4. 
Sidik, Muhammad. (2004). Telaah Ulang Wacana SEksualitas, Yogyakarta: PSW IAIN Sunan Kalijaga.

Sugihastuti dan Hariti Sastriyani, Siti. (2007). Glosaium Seks dan Gender, Yogyakarta: CarasvatiBooks.

Sumar, Warni Tune. (2015). .Implementasi Kesetaraan Gender dalm Bidang Pendidikan, MUSAWA, 7(1) .

Suratmaputra, Ahmad Munif. (2017). Kemaslahatan Sebagai Tujuan Pensyari'atan Hukum Islam. Misykar, 2, Desember. 